\title{
Intraventricular Lymphoplasmacyte-Rich Meningioma: A Case Report
}

\author{
Intraventriküler Lenfoplazmositten Zengin Menenjiyom: \\ Bir Olgu Sunumu
}

Yu-Bo WANG ${ }^{1}$, Wen-Jun WANG ${ }^{2}$, Song-Bai XU ${ }^{1}$, Bao-Feng XU ${ }^{1}$, Ying YU ${ }^{1}$, Hongxi MA³ ${ }^{3}$ Xian-Feng ZHANG ${ }^{1}$

${ }^{1}$ First Hospital of Jilin University, Department of Neurosurgery, Changchun, Jilin, P.R. China

${ }^{2}$ China-Japan Union Hospital of Jilin University, Department of Orthopedics, Changchun, Jilin, P.R. China

${ }^{3}$ First Hospital of Jilin University, Department of Pathology, Changchun, Jilin, P.R. China

Corresponding Author: Xian-Feng ZHANG / E-mail: xianfeng_zhangj1@163.com

\begin{abstract}
Lymphoplasmacyte-rich meningioma (LPM) is one of the rarest variants of meningioma and those LPMs that arise in the intraventricular space are even rarer. LPMs are classified as grade I (benign) tumors with a low proliferative rate and diagnosis is made through the histological identification of high numbers of inflammatory cells (lymphocytes and plasma cells) in the resected tumor tissue. In the current case, magnetic resonance imaging of a 37-year-old woman who presented at our neurosurgery department following a generalized tonic-clonic seizure revealed a partially mortified intraventricular mass, which had caused pronounced peritumoral edema and had a relatively rough surface. Surgical resection was performed. Histological analysis revealed large numbers of inflammatory cells, confirming the diagnosis of LPM, but also indicated that the lesion was positive for the proliferation marker Ki-67. Follow-up magnetic resonance imaging 3 months after surgery revealed no residual tumor or recurrence.
\end{abstract}

KEYWORDS: Lymphoplasmacyte-rich Meningioma, Lymphocyte, Plasmacyte, Intraventricular, Ki-67

öz

Lenfoplazmositten zengin menenjiyom (LPM), en nadir menenjiyom çeşitlerinden biridir ve intraventriküler boşluktan köken alan LPM'ler daha da nadirdir. LPM'ler düşük proliferatif hıza sahip derece I (benign) tümörler olarak sınıflandııılır ve tanı rezeksiyon yapılmış tümör dokusunda yüksek sayıda enflamatuvar hücrenin (lenfositler ve plazma hücreleri) histolojik olarak tanımlanması yoluyla konur. Mevcut olguda genel bir tonik-klonik nöbetten sonra beyin ve sinir cerrahisi bölümümüze gelen 37 yaşında bir kadında manyetik rezonans görüntüleme, peritümöral ödeme neden olmuş ve nispeten kaba bir yüzeye sahip kısmen gangrene bir intraventriküler kitle gösterdi. Cerrahi rezeksiyon yapıldı. Histolojik analiz LPM tanısını doğrulayacak şekilde yüksek sayıda enflamatuvar hücre gösterdi ama aynı zamanda lezyonun proliferasyon işareti Ki-67 pozitifliğini de ortaya koydu. Cerrahiden 3 ay sonra kontrol manyetik rezonans görüntüleme herhangi bir rezidüel tümör veya nüks göstermedi. ANAHTAR SÖZCÜKLER: Lenfoplazmositten zengin menenjiyom, Lenfosit, Plazmosit, İntraventriküler Ki-67

\section{INTRODUCTION}

Lymphoplasmacyte-rich meningioma (LPM) is a rare type of meningioma that is characterized histopathologically by massive infiltrates of inflammatory cells, such as lymphocytes and plasma cells. Despite its World Health Organization (WHO) classification as grade I (benign), the invasion of adjacent brain tissue is frequently seen by magnetic resonance imaging (MRI) (13). Nonetheless, the outcome of surgical resection without adjuvant therapy is generally favorable (25).

The symptoms of LPM vary according to the location, but some systemic hematological abnormalities, including hyperglobulinemia and iron refractory anemia, have been documented (7). Associated amyloid material and increased serum immunoglobulins have been described, though rarely (9).

Since it was first described in 1971 by Banerjee and Blackwood (2), 36 cases of LPM have been reported. None have been intraventricular in origin. Indeed, intraventricular meningiomas are extremely rare compared to those of other locations, accounting for only $0.5-3 \%$ of all meningiomas (22). Most intraventricular tumors arise in the lateral ventricle and over $90 \%$ occur in the trigone $(3,17)$. Here we report an LPM that originated in the intraventricular trigone.

\section{CASE REPORT}

A 37-year-old woman was admitted to our neurosurgery department 5 hours after suffering a generalized tonic-clonic seizure. She had no prior history of seizure activity and a neurological examination showed no abnormalities. MRI revealed an intraventricular mass that had caused marked peritumoral edema. The mass measured approximately $3 \mathrm{~cm}$ in diameter. Compared with gray matter, the lesion was slightly hypointense on T1-weighted MRI and hyperintense on T2-weighted MRI. It was strongly enhanced after Gd-diethylenetriamine pentaacetic acid administration (Figure $1 \mathrm{~A}-\mathrm{C}$ ). The lesion 
appeared to have a relatively rough surface (Figure $1 \mathrm{E}$ ) and was partially mortified (Figure 1A).

The patient underwent a right occipitotemporal craniotomy for symptomatic improvement. A grayish-pink mass originating from the intraventricular trigone and measuring $3 \times 3 \times 4$ $\mathrm{cm}$ was completely removed. The neoplasm closely adhered to the lateral ventricular walls and choroid plexus but had a complete tumor capsule. Superficially, the resected tumor mass was gritty. Hematoxylin and eosin (H\&E) staining revealed multiple nests of meningothelial cells and abundant collagen fibers with a dense infiltration of lymphocytes and plasma cells (Figure 2A). Immunohistochemical staining (Figure $2 \mathrm{~B}-\mathrm{J}$ ) revealed that the lesion was positive for epithelial membrane antigen (EMA), vimentin, Ki-67, kappa, lambda, CD3, CD20, and CD138, but negative for neuron-specific enolase (NSE), glial fibrillary acidic protein (GFAP), and progesterone receptor (PR).

Following surgery, the patient had intermittent fever with a maximal temperature of $38.5^{\circ} \mathrm{C}$. Red blood cells $(1,000 \times$ $\left.10^{6} / \mathrm{L}\right)$ and white blood cells $\left(53 \times 10^{6} / \mathrm{L}\right)$ were found in the cerebrospinal fluid (CSF) by routine CSF analysis. Blood and CSF cultures were sterile. The intermittent fever resolved with symptomatic treatment 4 days after surgery. The rest of the postoperative course was uneventful and the outcome was favorable. The patient has returned to normal activities without sequelae or epilepsy. Follow-up MRI revealed no residual tumor or recurrence 3 months after surgery (Figure 1D-F).

\section{DISCUSSION}

\section{An Introduction to LPM}

LPM was histologically classified as a rare variant of meningioma by the WHO in 1993 (12). It features extensive chronic inflammatory infiltrates that often overshadow the inconspicuous meningothelial component in the pathology findings. The categorization of LPM as a distinct clinicopathologic entity remains controversial, since its behavior often resembles that of an inflammatory process $(5,16)$. Indeed, some re-
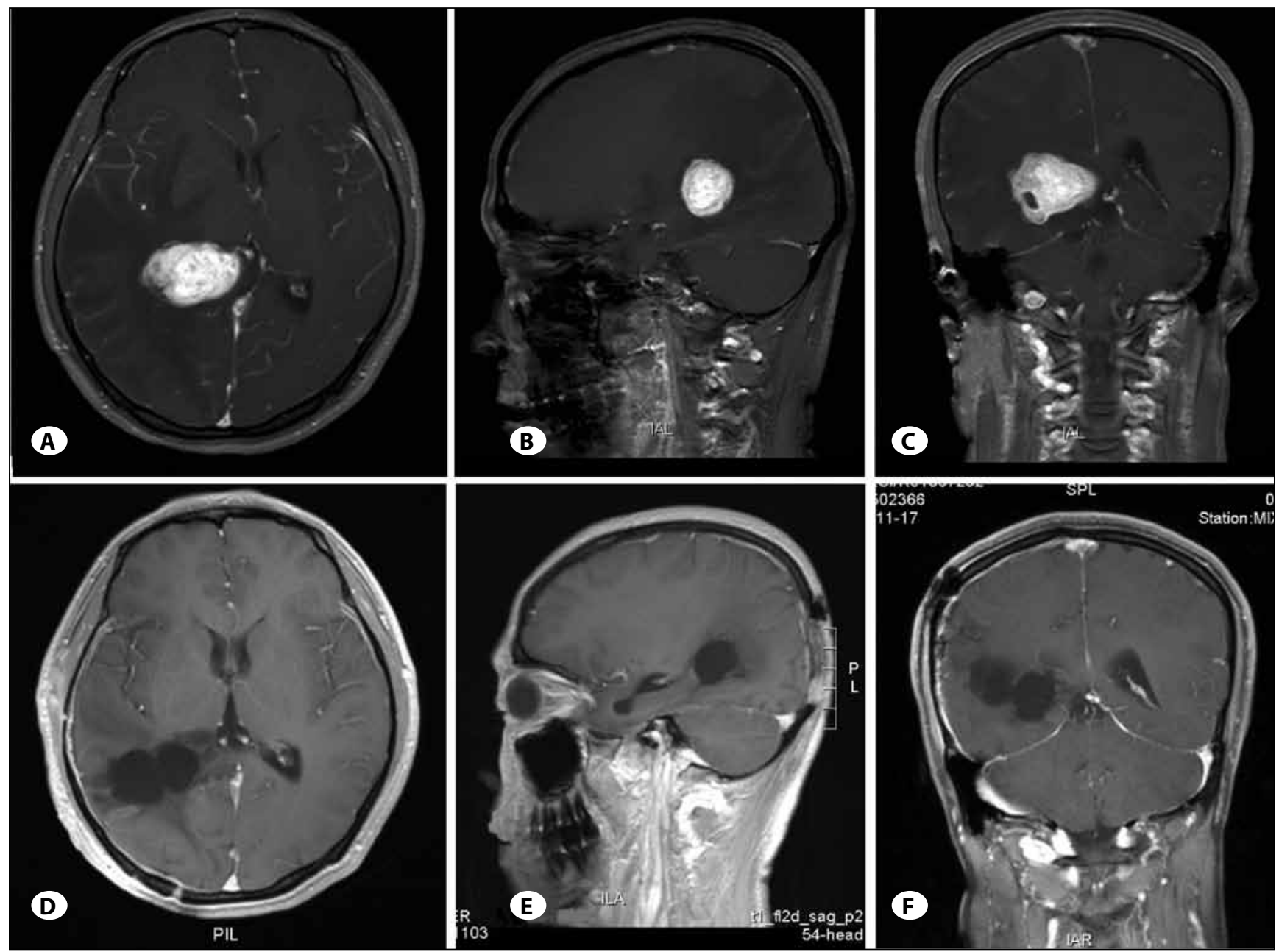

Figure 1: Preoperative and postoperative MRI results. Preoperative MRI of the brain with Gd-diethylenetriamine pentaacetic acid contrast agent revealed an enhanced irregular lesion (A, axial view; B, sagittal view; C, coronal view). MRI scanning at 3 months after the operation showed that the tumor was completely resected; no recurrence was observed (D, axial view; E, sagittal view; $\mathbf{F}$, coronal view). 
searchers have suggested that the nature of LPM is that of a primary meningioma with prolonged immunological stimulation by plasma cells or a meningothelial reaction secondary to chronic inflammation (25).

\section{Clinical Findings}

LPM belongs to WHO grade I meningiomas, which means that the risk of recurrence and aggressive growth is low. In the present case, however, immunohistochemical staining revealed that the tumor cells were positive for the proliferation marker Ki-67. The preoperative MRI revealed that the tumor had a relatively rough surface and was partially mortified. This is not the first report of a LPM showing positive staining for Ki-67: Nohara et al. (21) reported a 12-year-old boy who presented with a LPM in the posterior fossa. Histological examination showed that the tumor had invaded the normal brain tissue and that the Ki-67 labeling index, determined by using a MIB-1 monoclonal antibody, was relatively high. The authors concluded that LPM can exhibit an atypical invasive nature (21).

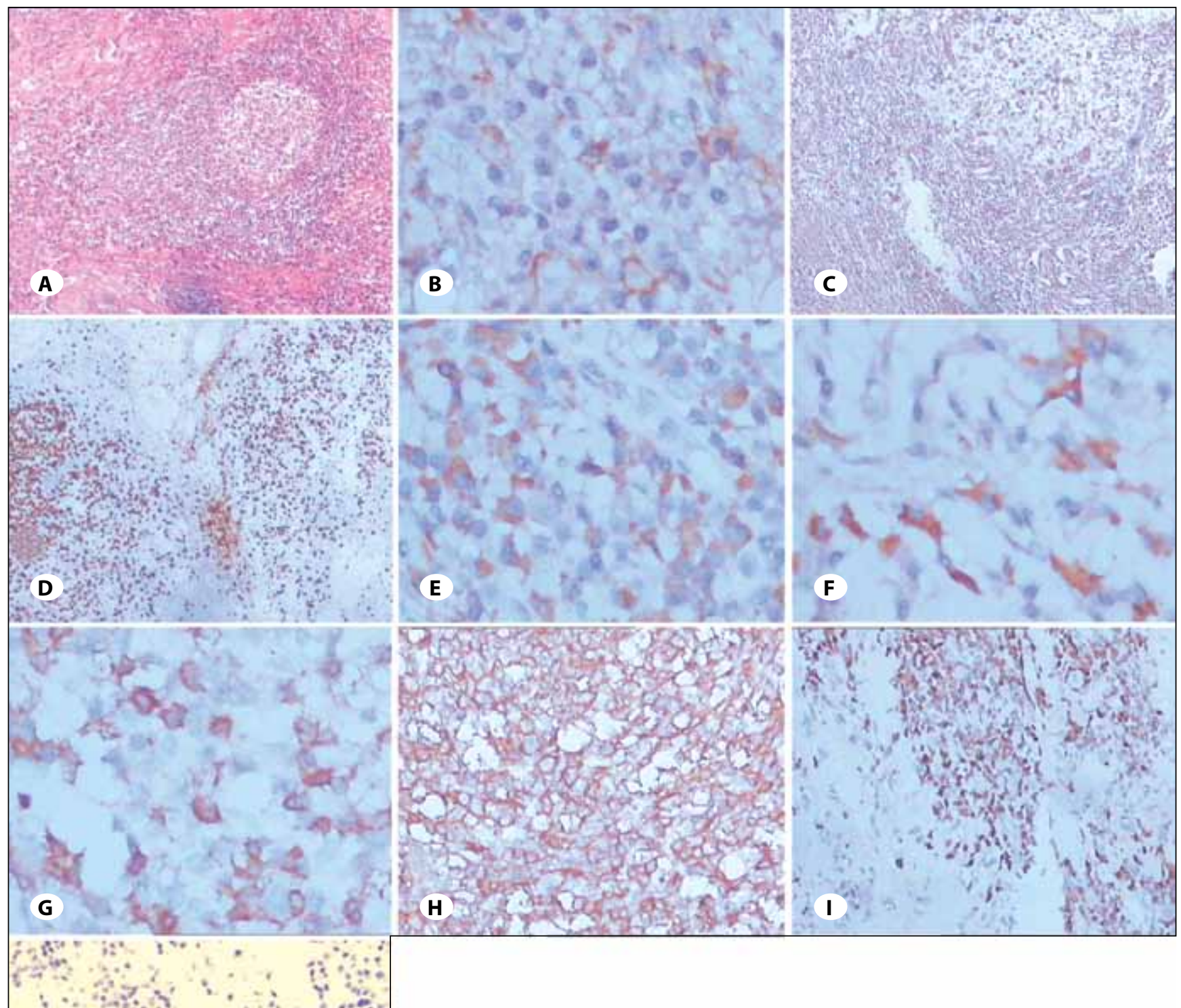

Figure 2: Microscopic characteristics of the resected tumor tissue. A) Hematoxylin and eosin staining of the resected tumor tissue revealed abundant collagen fibers with a dense infiltration of lymphocytes and plasma cells $(\times 40)$. Immunohistochemical staining revealed that the lesion were positive for B) EMA $(\times 400)$, C) vimentin $(\times 40)$, D) Ki-67 (×100), E) kappa (×400), F) lambda (×400), G) CD3 (×400), H) CD20 (×200), and I) CD138 ( $\times 40)$. J) The lesion was negative for progesterone receptor $(\times 400)$. 


\section{Literature Review}

In a review of the literature conducted via PubMed with the keywords "lymphocyte", "plasmacyte", and "meningioma", 23 papers (Table I), including the present case, reported LPMs $(10,13,20,25)$, with 37 cases in total. With 21 female and 16 male patients, the female:male ratio was 1.3:1. The age of onset ranged from 4 to 72 with a mean of 35.6 years. Multiple lesions are more frequent in LPM than in typical meningioma with $16.2 \%$ of these 37 cases involving multiple lesions, a rate that is only $1-3 \%$ for typical meningiomas (5). The most frequent locations of LPM are the convexity, and the cerebellopontine angle (CPA).
With regard to tumor appearance, analysis of the MRI results and the pathology of the LPM suggests that its appearance is different from ordinary meningioma (13). LPM tumor features include flat growth along the meninges, an irregular shape, an unclear boundary, prominent edema, a notable sensitivity to contrast enhancement, invasion of adjacent brain tissues, and a characteristic inflammation.

Surgical resection was the treatment of choice in the 37 cases and few showed tumor progression after resection. There is no standard adjuvant therapy for residual or recurrent tumor after surgical resection. Gamma knife radiosurgery with a low

Table I: Review of the Literature via Pubmed with the Keywords "Lymphocyte", Plasmacyte" and "Meningioma”

\begin{tabular}{|c|c|c|c|c|c|c|}
\hline Author & Year & Age & Gender & Location & Treatment & Outcome \\
\hline Banerjee et al. (2) & 1971 & 71 & M & Subfrontal & Resection & Well \\
\hline \multirow[t]{5}{*}{ Horten et al. (9) } & 1979 & 15 & $\mathrm{~F}$ & CPA & Resection, radiation, chemotherapy & Dead \\
\hline & 1979 & 53 & $\mathrm{~F}$ & Foramen magnum & Resection & Well \\
\hline & 1979 & 52 & $\mathrm{~F}$ & Falx & Resection & Well \\
\hline & 1979 & 22 & M & Parasagittal & Resection & Well \\
\hline & 1979 & 4 & M & CPA & Resection & Well \\
\hline Stam et al. (24) & 1980 & 59 & M & Falcotentorial & Resection & Not described \\
\hline \multirow[t]{2}{*}{ Mirra et al. (18) } & 1983 & 11 & $\mathrm{~F}$ & Multiple & Resection & Well \\
\hline & 1983 & 39 & $\mathrm{~F}$ & Spinal canal & Resection & Expansion \\
\hline Gi et al. (7) & 1990 & 8 & M & Multiple & Resection, radiation & Recurrence \\
\hline Loiseau et al. (15) & 1995 & 11 & $\mathrm{~F}$ & Multiple & Resection & Well \\
\hline \multirow[t]{2}{*}{ Yamaki et al. (26) } & 1997 & 22 & M & Multiple & Resection & Well \\
\hline & 1997 & 24 & $\mathrm{~F}$ & Clival & Resection & Recurrence \\
\hline Mizushima et al. (19) & 1997 & 64 & $\mathrm{~F}$ & Parasagittal & Resection & Well \\
\hline Katayama et al. (11) & 1997 & 47 & $\mathrm{~F}$ & Convexity & Resection & Well \\
\hline \multirow[t]{3}{*}{ Yoneyama et al. (27) } & 1999 & 36 & $M$ & Convexity & Resection & Recurrence \\
\hline & 1999 & 41 & $\mathrm{~F}$ & Convexity & Resection & Well \\
\hline & 1999 & 22 & M & Falx & Resection & Well \\
\hline Pittella et al. (23) & 2001 & 47 & M & Spinal canal & Resection & Dead \\
\hline Bruno et al. (5) & 2004 & 45 & $\mathrm{~F}$ & Convexity & Resection & Well \\
\hline Loh et al. (14) & 2006 & 22 & $\mathrm{~F}$ & Sphenoid ridge & Resection & Well \\
\hline $\begin{array}{l}\text { Hirunwiwatkul et al. } \\
\text { (8) }\end{array}$ & 2007 & 24 & $M$ & Multiple & Resection & Well \\
\hline Nohara et al. (21) & 2007 & 12 & M & CPA & Resection & Well \\
\hline Ghosal et al. (6) & 2007 & 25 & M & Convexity & Resection & Well \\
\hline Avninder et al. (1) & 2008 & 22 & $\mathrm{~F}$ & Foramen magnum & Resection & Well \\
\hline Bodi et al. (4) & 2008 & 72 & $\mathrm{~F}$ & Convexity & Resection & Well \\
\hline Liu et al. (13) & 2010 & $\begin{array}{c}38 \\
\text { (mean) }\end{array}$ & $\begin{array}{l}\text { M4 } \\
\text { F3 }\end{array}$ & Not clear & Not described & Not described \\
\hline Kanno et al. (10) & 2011 & 55 & $\mathrm{~F}$ & Jugular foramen & Resection & Well \\
\hline Wang et al. (25) & 2011 & 62 & $\mathrm{~F}$ & Multiple & Resection, radiation & Well \\
\hline Nakayama et al. (20) & 2012 & 37 & $\mathrm{~F}$ & Convexity & Resection & Well \\
\hline Present case & 2013 & 37 & $\mathrm{~F}$ & Intraventricular & Resection & Well \\
\hline
\end{tabular}

CPA: cerebellopontine angle, F: female, $\mathbf{M : \text { male. }}$ 
peripheral dose may have an effective role in the treatment of LPM (25).

In the present case, meningioma was suspected due to the clinical presentation and MRI examination. The rough edge and pronounced peritumoral edema were indicative of an aggressive meningioma, a diagnosis that was supported by the close adherence of the tumor to the lateral ventricular walls and choroid plexus and its intact tumor capsule. The H\&E pathology results, however, indicated that it was an inflammatory pseudotumor. A review of the literature suggested LPM, which was confirmed by positive immunohistochemical staining for EMA and vimentin. Although the patient developed a fever after surgery, blood and CSF analysis did not indicate a bacterial infection. Two possible causes of fever are a febrile response after surgery or blood left in the subarachnoid space after the craniotomy, but the relationship between the inflammation caused by LPM and the fever is still unclear. There was no recurrence of the tumor after 3 months of follow-up.

In conclusion, we have reported a case of intraventricular LPM in a 37-year-old woman who presented with occasional seizures. The definitive diagnosis of LPM relied on histopathological findings. LPM is very rare, particularly when located in the intraventricular space. We believe that total excision remains the treatment option of choice for such patients.

\section{REFERENCES}

1. Avninder S, Gupta V, Sharma KC: Lymphoplasmacyte-rich meningioma at the foramen magnum. $\mathrm{Br} J$ Neurosurg 22: 702-704, 2008

2. Banerjee AK, Blackwood W: A subfrontal tumour with the features of plasmocytoma and meningioma. Acta Neuropathol 18: 84-88, 1971

3. Bertalanffy A, Roessler K, Koperek O, Gelpi E, Prayer D, Neuner M, Knosp E: Intraventricular meningiomas: A report of 16 cases. Neurosurg Rev 29: 30-35, 2006

4. Bodi I, Hortobagyi T, Buk S: A 72-year-old woman with right frontal extra-axial mass. Brain Pathol 18: 279-282, 2008

5. Bruno MC, Ginguene C, Santangelo M, Panagiotopoulos K, Piscopo GA, Tortora F, Elefante A, De Caro ML, Cerillo AS: Lymphoplasmacyte rich meningioma. A case report and review of the literature. J Neurosurg Sci 48: 117-124, 2004

6. Ghosal N, Furtado SV, Santosh V, Sridhar M, Hegde AS: Coexisting fibrous dysplasia and atypical lymphoplasmacyterich meningioma. Neuropathology 27: 269-272, 2007

7. Gi H, Nagao S, Yoshizumi H, Nishioka T, Uno J, Shingu T, Fujita Y: Meningioma with hypergammaglobulinemia. Case report. J Neurosurg 73: 628-629, 1990

8. Hirunwiwatkul P, Trobe JD Blaivas M: Lymphoplasmacyterich meningioma mimicking idiopathic hypertrophic pachymeningitis. J Neuroophthalmol 27: 91-94, 2007

9. Horten $\mathrm{BC}$, Urich $\mathrm{H}$, Stefoski D: Meningiomas with conspicuous plasma cell-lymphocytic components: A report of five cases. Cancer 43: 258-264, 1979

10. Kanno H, Nishihara H, Hara K, Ozaki Y, Itoh T, Kimura T, Tanino M, Tanaka S: A case of lymphoplasmacyte-rich meningioma of the jugular foramen. Brain Tumor Pathol 28: 341-345, 2011
11. Katayama S, Fukuhara T, Wani T, Namba S Yamadori I: Cystic lymphoplasmacyte-rich meningioma--case report. Neurol Med Chir (Tokyo) 37: 275-278, 1997

12. Kleihues P, Burger PC, Scheithauer BW, Z Lch KJ, World Health Organization: Histological typing of tumours of the central nervous system. Berlin, New York, Geneva: Springer-Verlag; World Health Organization, 1993

13. Liu JL, Zhou JL, Ma YH, Dong C: An analysis of the magnetic resonance imaging and pathology of intracal lymphoplasmacyte-rich meningioma. Eur J Radiol 81: 968-973, 2012

14. Loh JK, Hwang SL, Tsai KB, Kwan AL, Howng SL: Sphenoid ridge lymphoplasmacyte-rich meningioma. J Formos Med Assoc 105: 594-598, 2006

15. Loiseau H, Pedespan JM, Vital A, Marchal C, Vital C, Cohadon F: Lymphoplasmacyte-rich meningioma in a child. Case report. J Neurosurg 83: 1075-1079, 1995

16. Louis DN. International Agency for Research on Cancer: WHO classification of tumours of the central nervous system. Lyon: International Agency for Research on Cancer, 2007

17. Lyngdoh BT, Giri PJ, Behari S, Banerji D, Chhabra DK, Jain VK: Intraventricular meningiomas: A surgical challenge. J Clin Neurosci 14: 442-448, 2007

18. Mirra SS, Tindall SC, Check IJ, Brynes RK, Moore WW: Inflammatory meningeal masses of unexplained origin. An ultrastructural and immunological study. J Neuropathol Exp Neurol 42: 453-468, 1983

19. Mizushima M, Tanaka Y, Kawakami S, Hori T, Ohama E: Lymphoplasmacyte-rich meningioma: A case report with histological and immunohistochemical studies. Brain Tumor Pathol 14: 59-62, 1997

20. Nakayama Y, Watanabe M Suzuki K, Usuda H, Emura I, Toyoshima Y, Takahashi H, Kawaguchi T, Kakita A: Lymphoplasmacyte-rich meningioma: $A$ convexity mass with regional enhancement in the adjacent brain parenchyma. Neuropathology 32: 174-179, 2012

21. Nohara H, Furuya K, Kawahara N, lijima A, Yako K, Shibahara J, Kirino T: Lymphoplasmacyte-rich meningioma with atypical invasive nature. Neurol Med Chir (Tokyo) 47: 32-35, 2007

22. Odegaard KM, Helseth E, Meling TR: Intraventricular meningiomas: A consecutive series of 22 patients and literature review. Neurosurg Rev 36:57-64 2012

23. Pittella JE, Da Costa CC, Giannetti AV, Perpetuo FO: October 2000: A 47 year old man with long-standing progressive tetraparesis. Brain Pathol 11: 261-262, 2001

24. Stam FC, van Alphen HA, Boorsma DM: Meningioma with conspicuous plasma cell components. A histopathological and immunohistochemical study. Acta Neuropathol 49: 241-243, 1980

25. Wang WH, Lee CC, Lin SC, Guo WY, Ho DM, Chen MH, Pan $\mathrm{DH}$, Shih YH, Chen MT: Gamma knife radiosurgery for lymphoplasmacyte-rich meningioma. Clin Neurol Neurosurg 115:1110-1113, 2013

26. Yamaki T, Ikeda T, Sakamoto Y, Ohtaki M, Hashi K: Lymphoplasmacyte-rich meningioma with clinical resemblance to inflammatory pseudotumor. Report of two cases. J Neurosurg 86: 898-904, 1997

27. Yoneyama T, Kasuya $\mathrm{H}$, Kubo $\mathrm{O}$, Hori T: Lymphoplasmacyterich meningioma: A report of three cases and a review of the literature. No Shinkei Geka 27: 383-389, 1999 